\title{
Penurunan Total Harmonic Distortion (THD) Pada Penguat Audio Kelas D Menggunakan MQPSO
}

\author{
Moh Uhida Subhan ${ }^{1}$, Ponco Siwindarto ${ }^{2}$, Bambang Siswojo ${ }^{3}$ \\ 1uhida2000@gmail.com, ${ }^{2}$ ponco@ub.ac.id, ${ }^{3}$ bsiswoyo@ub.ac.id \\ Progam Studi Teknik Elektro, Universitas Brawijaya
}

\begin{abstract}
Class D audio amplifier is an audio switching amplifier that has a high efficiency compared to conventional (analog) audio amplifiers. Under ideal conditions, this amplifier has an efficiency of more than 90\%. A common problem that occurs in this amplifier is distortion because it works non-linearly. A Proportional Integral (PI) compensator is used as an analog filter on negative feedback compared to the trial and error method with the Modified Particle Swarm Optimization (MQPSO) method to reduce Total Harmonic Distortion (THD) on a system. The MQPSO method has advantages in performance, which is a simple process, implementing it to the system is very easy and in the calculation is very efficient. The results show that the THD value without optimization is $13.53 \%$ while the additional MQPSO method is $13.46 \%$ with the FFT Tool Simulink Matlab V17 with an optimal THD difference of $0.07 \%$. While the stability testing time consisting of parameters C2, R2, and R1 obtained THD $0.116 \%$ at $0.174 \mathrm{~s}$ without optimization and $0.113 \mathrm{~s}$ using optimization with a time difference of 0.063 s to achieve stability.
\end{abstract}

Intisari - Penguat audio kelas D merupakan penguat audio switching yang mempunyai efisiensi tinggi dibanding penguat audio konvensional (analog). Dalam kondisi ideal, penguat ini mempunyai efisiensi lebih dari $90 \%$. Permasalahan umum yang terjadi pada penguat ini adalah distorsi karena bekerja secara non linier. Sebuah kompensator Proportional Integral (PI) digunakan sebagai filter analog pada umpan balik negatif dibandingkan antara metode trial dan error dengan metode Modified Particle Swarm Optimization (MQPSO) untuk mengurangi Total harmonic Distortion (THD) pada sebuah sistem. Metode MQPSO memiliki keunggulan dalam kinerja yaitu proses sederhana, implementasikan ke sistem sangat mudah dan didalam perhitungan sangat efisien. Hasilnya menunjukkan bahwa nilai THD tanpa optimasi $13.53 \%$ sedangkan dengan tambahan metode MQPSO sebesar 13.46\% dengan FFT Tool Simulink Matlab V17 dengan selisih THD optimal sebesar $0.07 \%$. Sedangkan pengujian waktu kestabilan yang terdiri dari parameter C2, R2, dan R1 didapatkan THD $0.116 \%$ pada 0.174 s tanpa optimasi dan $0.113 s$ menggunakan optimasi dengan selisih waktu sebesar 0.063s untuk mencapai kestabilan.

\section{Kata Kunci-Penguat Audio; Kelas D; THD; MQPSO}

\section{PENDAHULUAN}

Perkembangan teknologi elektronik saat ini berkembang pesat. Hal ini dapat dilihat dari berbagai perangkat elektronik di bidang audio visual semula mempunyai bentuk yang cukup besar dengan kebutuhan daya tinggi, saat ini berubah menjadi perangkat yang sederhana dengan konsumsi daya rendah.
Perangkat elektronik seperti televisi LED, Notebook, smartphone, dan perangkat portabel lainnya sebagai contoh perkembangan teknologi elektronik [1], [2]. Setiap perangkat elektronik tersebut dilengkapi sistem penguat audio yang mengharuskan perangkatnya mempunyai bentuk yang dapat disesuaikan, konsumsi daya rendah, efisiensi tinggi dan linieritas yang baik. Perkembangan teknologi seperti ini, menjadi tantangan besar untuk menghadirkan penguat audio dengan persyaratan tersebut [2], [3]. Penguat audio analog yang dikategorikan sebagai kelas $\mathrm{A}, \mathrm{B}, \mathrm{AB}$, mempunyai efisiensi kurang dari $80 \%$ dan membutuhkan daya yang tinggi [4]. Dalam kondisi ideal, Penguat audio kelas A mempunyai efisiensi daya maksimal sebesar 25\%, kelas B $78 \%$ dan kelas AB mendekati 78\% [5]. Melihat efisiensi pada penguat audio analog di bawah $80 \%$, dirancang penguat audio switching (digital) yang mempunyai efisiensi lebih dari 90\% [6]. Sebagai penguat non linier, distorsi harmonik menjadi permasalahan tersendiri yang dapat mempengaruhi efisiensi dan kejernihan suara dari penguat audio.

Beberapa penelitian telah dikembangkan pada Penguat audio kelas D untuk mengurangi distorsi dan meningkatkan efisiensi antara lain penelitian yang dikhususkan pada sistem umpan balik negatif menggunakan inverter base OTAs [2], menggunakan PWM feedback loop [7], dan sistem selfoscillating modulation with complete feedback network [4]. Sistem umpan balik negatif terbukti dapat memperkecil Total harmonic Distortion (THD) dan meningkatkan efisiensi [6]. Sistem umpan balik negatif pada penelitian ini [2] menggunakan rangkaian Kompensator Proportional Integral (PI) untuk memperbaiki dari sistem umpan balik negatif menggunakan rangkaian integrator yang belum maksimal dalam menekan distorsi harmonik yang dihasilkan oleh inti ferit dari low pass filter (LPF). Permasalahan pada Kompensator PI ini terletak pada penalaan gain yang sangat berpengaruh pada kestabilan sistem.

Kompensator PI terdiri atas rangkaian umpan balik R dan C. Kontrol PI pada kompensator berfungsi untuk memperkecil error dan menstabilkan sistem pada frekuensi rendah [2]. Untuk memperoleh parameter nilai $\mathrm{R}$ dan $\mathrm{C}$ yang optimal pada Kompensator PI bukan pekerjaan yang mudah. Oleh karena itu, diperlukan proses pelatihan dan pembelajaran (training and learning) dengan menggunakan metode optimasi untuk menala parameter-parameter Kompensator PI [8]. Penelitian yang relevan sebagai acuan optimasi pada rangkaian kompensator adalah penelitian tentang optimasi low pass filter analog butterworth orde 4 [9]. Algoritma yang digunakan pada penelitian ini dengan membandingkan Algoritma Particle Swarm Optimization (PSO), Artificial Bee Colony (ABC), Ant Colony (ACO) dan Algoritma Genetika (GA). Penggunaan algoritma ini digunakan untuk mencari nilai resistor dan capacitor yang optimal dengan mencari faktor error terkecil. 


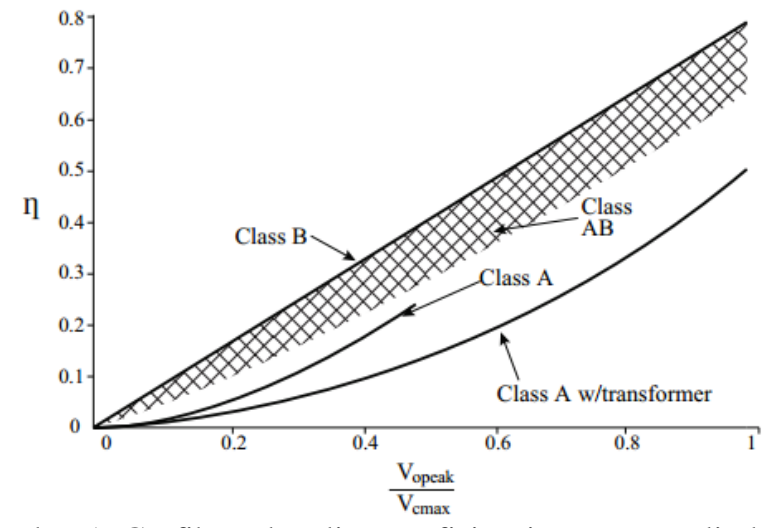

Gambar 1. Grafik Perbandingan efisiensi penguat audio kelas A, B dan $\mathrm{AB}$

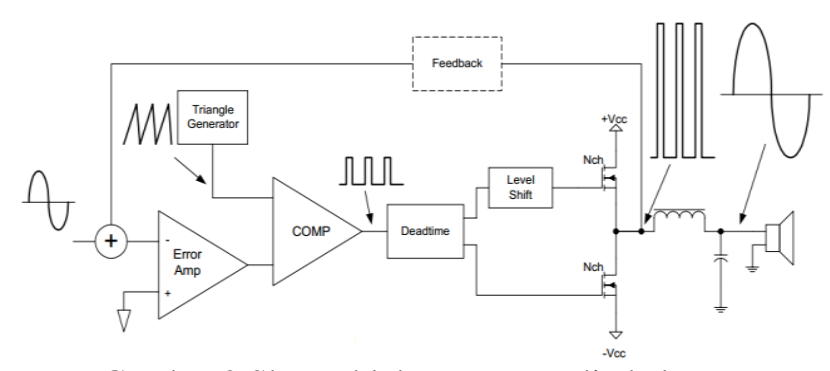

Gambar 2 Skema blok penguat audio kelas D.

Pada penelitian selanjutnya [10] menggunakan Metode optimasi Modified Particle Swarm Optimization (MQPSO) yang merupakan pengembangan dari algoritma Particle Swarm Optimization (PSO) dan Quantum behaved Particle Swarm Optimization (QPSO) pada perangkat elektromagnetik. Hasilnya, metode MQPSO ini mempunyai pencarian global yang lebih baik dan kecepatan konvergensi yang lebih cepat dibandingkan dengan metode optimal lainnya yang diuji antara lain GQPSO, QPSO, LIQPSO.

Pada penelitian ini diusulkan perancangan Kompensator PI yang dioptimasi menggunakan metode optimasi Modified Quantum behaved Particle Swarm Optimization (MQPSO). Hasil yang diharapkan dari simulasi Penguat kelas D adalah Penurunan THD dan mempercepat kestabilan sistem Penguat audio kelas D menggunakan Metode Modified Quantum behaved Particle Swarm Optimization (MQPSO).

\section{METODE PENELITIAN}

\section{A. Penguat Audio Konvensional (Analog)}

Penguat audio digunakan untuk memperkuat sinyal (seperti musik atau vokal) yang berada dalam frekuensi sinyal yang bisa didengar manusia pada frekuensi $20 \mathrm{~Hz}$ hingga $20 \mathrm{kHz}$ [11]. Hal ini bertujuan untuk meningkatkan kekuatan sinyal inputnya sehingga cukup untuk mendorong impedansi beban pasif yang relatif rendah, seperti speaker audio [12].

Selain linieritas sinyal output, yang perlu diperhatian dalam merancang tingkatan output amplifier adalah efisiensi dayanya [13]. Tingkatan output dari penguat daya harus memberikan kekuatan sinyal yang diperlukan untuk beban yang efisien. Dengan kata lain, daya yang dikonsumsi oleh daya output transistor harus dijaga serendah mungkin. Ini sangat penting terutama di perangkat portabel di mana sumber daya terbatas. Daya yang hilang dalam transistor daya diubah menjadi energi panas secara permanen yang dapat merusak

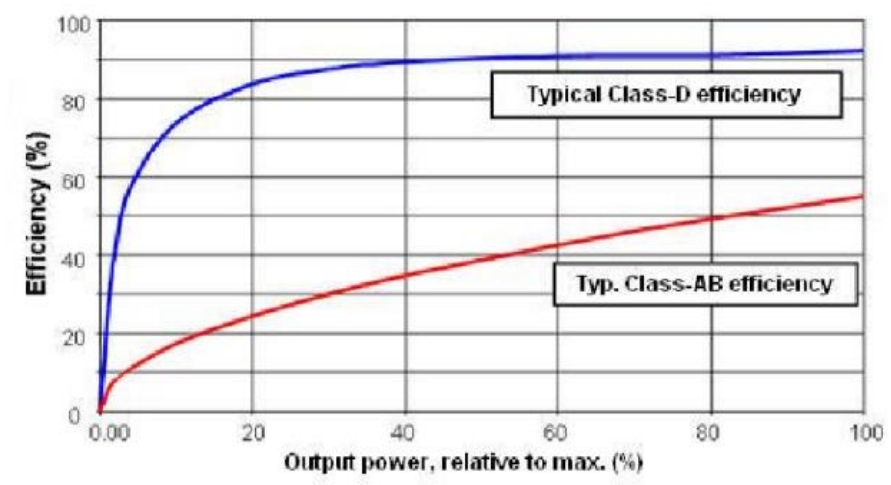

Gambar 3. Grafik Perbandingan efisiensi penguat audio kelas $\mathrm{AB}$ dan $\mathrm{D}$

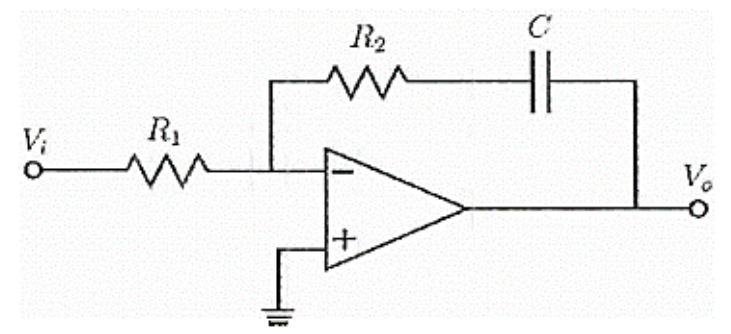

Gambar 4. Realisasi Kompensator PI

perangkat output. Dengan demikian, dibutuhkan penggunaan heat sink (pendingin) untuk mengurangi energi panas pada output transistor. Akibatnya, ada penambahan biaya dan ukuran dari perangkat tersebut. Sedangkan perbandingan efisiensi pada penguat audio kelas $\mathrm{A}, \mathrm{B}$, dan $\mathrm{AB}$ dapat dilihat pada Gambar 1 yang menunjukkan efisiensi penguat audio kelas AB berada diantara penguat audio kelas A dan B.

\section{B. Penguat Audio Switching (Digital)}

Penguat audio kelas D pertama kali dikenalkan pada tahun 1958, dan telah menjadi semakin populer dalam beberapa tahun terakhir yang pada dasarnya adalah Switchingamplifier atau Pulse Width Modulation-Amplifier yang bekerja dengan prinsip binary-switches. Sejak digunakannya power MOSFET, maka menjadikan binary-switches lebih sempurna, sehingga tidak ada waktu transisi terbuang dan tidak ada daya terbuang [14].

Penguat audio kelas D memiliki efisiensi yang jauh lebih baik dibandingkan penguat-penguat audio pendahulunya seperti penguat kelas A, kelas B dan kelas AB. Saat ini penguat audio kelas D mempunyai efisiensi $90 \%$ saat dibebani speaker. Sementara secara teoritis penguat audio Kelas D mempunyai efisiensi ideal $100 \%$ [15].

Sinyal masukan adalah sinyal audio standar sinusoida dengan frekuensinya antara $20 \mathrm{~Hz}-20 \mathrm{KHz}$. Selanjutnya sinyal audio ini akan di bandingkan/dikomparasikan dengan sinyal frekuensi tinggi $(250 \mathrm{KHz})$ yang berbentuk segitiga ataupun gigi gergaji, yang akhirnya menghasilkan sinyal PWM seperti terlihat pada Gambar 2 [16].

Selanjutnya sinyal PWM ini diumpankan ke tingkat akhir dan dikuatkan oleh perangkat tingkat akhit (Mosfet), lalu di lewatkan rangkaian LPF dan output LPF diumpankan ke speaker. Diharapkan output LPF sinyalnya berbentuk sinusoida kembali yang diperlihatkan pada Gambar 2. 


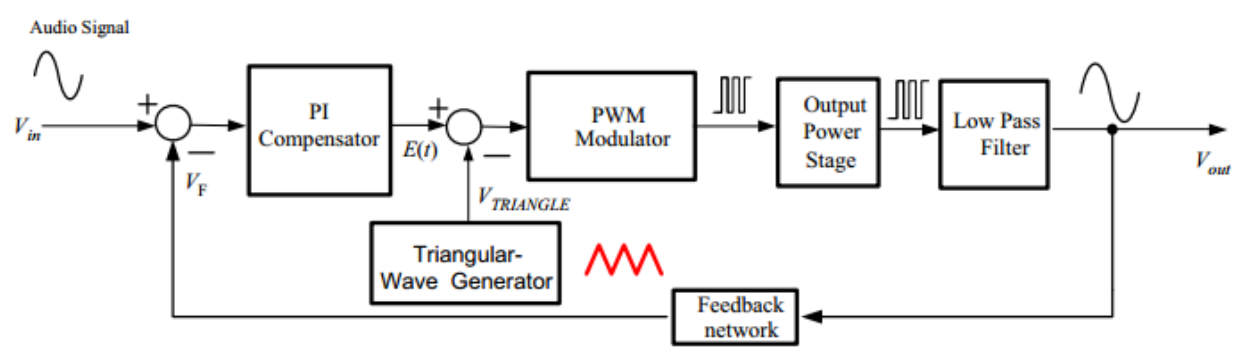

Gambar 5 Pemodelan loop tertutup dengan Kompensator PI

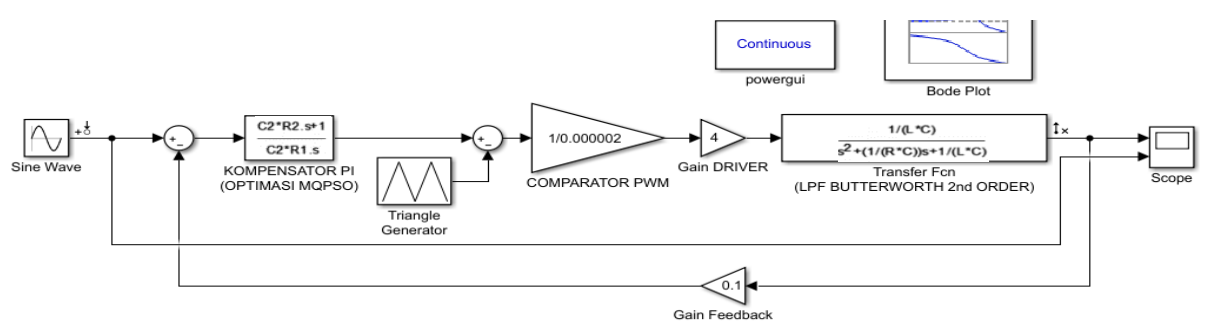

Gambar 6 Model Matlab Simulink V17 Penguat audio kelas D dengan Metode

Low Pass Filter (LPF), bertugas untuk menyaring komponen frekuensi rendah yang terpakai hasil output rangkaian akhir Switching. Output dari LPF ini merupakan replika skala dari sinyal masukannya. Total Harmonik Distortion (THD) selalu menjadi parameter utama untuk menentukan linieritas sebuah penguat audio kelas d. THD dapat didefinisikan Persamaan (1).

$\% \mathrm{THD}=\frac{\sqrt{V_{\text {OUT }}^{2} @ 2 f+V_{\text {OUT }}^{2} @ 3 f+V_{\text {OUT }}^{2} @ 4 f \ldots}}{V_{\text {OUT }} @ f} \times 100$

$\mathrm{V}_{\text {out } @ \mathrm{f}} \quad=$ Tegangan frekuensi dasar

$\mathrm{V}_{\text {out } @ 2,3,4 \mathrm{fdst}} \quad=$ Tegangan frekuensi harmonic

Sedangkan perbandingan efisiensi penguat audio kelas $\mathrm{AB}$ dan kelas D ditunjukkan pada Gambar 3.

\section{Kompensator Proportional Integral (PI)}

Kompensator PI (Proporsional Integral) pada Gambar 4 merupakan kontroler yang mengabungkan 2 buah jenis kontroler dengan karakteristiknya masing-masing. Kekurangan pengendali proporsional dapat dihilangkan dengan memasukkan elemen pengendali integral.

Kendali proporsional dapat cenderung menstabilkan sistem dan kendali integral dapat cenderung menghilangkan atau memperkecil galat keadaan tunak dari tanggapan terhadap berbagai masukan [17]. Fungsi alih kompensator PI dapat ditulis pada Persamaan (2).

$$
G_{C}(S)=\frac{s C_{2} R_{2}+1}{s C_{2} R_{1}}
$$

\section{Modified Quantum Behaved Particle Swarm Optimization (MQPSO)}

Metode optimasi MQPSO merupakan pengembangan dari algoritma Particle Swarm Optimization (PSO) dan Quantum Behaved Particle Swarm Optimization (QPSO). MQPSO (Modified QPSO) merupakan variasi dari QPSO dengan merubah nilai mbest yang merupakan rata-rata nilai dari pbest menjadi nilai gbest untuk menghasilkan pencarian yang lebih spesifik [18]. Oleh karena itu perhitungan posisi partikel dari MQPSO pada Persamaan (3).

$x_{i}(t+1)=p_{i} \pm \alpha g \mid$ gbest $-x_{i}(t) \mid * \ln \left(\frac{1}{u}\right) u \approx U(0,1)$

MQPSO melakukan pencarian secara global pada awal iterasi dan semakin lama pencarian secara lokal dilakukan pada Persamaan (4).

$\alpha=\left(\alpha_{0}-\alpha_{1}\right) *\left(\frac{\text { iter }}{\max \text { iter }}\right)+\alpha_{1}$

\section{E. Perancangan Simulasi Penguat audio kelas D}

Perancangan sistem Penguat audio kelas D ini dilakukan dengan membuat simulasi rangkaian loop tertutup dengan sebuah Kompensator PI sebagai filter analog dari sebuah sistem menggunakan Software Multisim V14.0 dan Matlab Simulink V17. Perbandingan antara sistem dengan Kompensator PI sebelum dioptimasi dan setelah dioptimasi menggunakan metode MQPSO akan dianalisis hasil THD yang dihasilkan dan waktu yang dibutuhkan untuk mencapai THD terkecil.

Penguat audio kelas D loop tertutup terkompensasi terdiri dari modulator PWM, generator gelombang segitiga, Penguat daya output (Switching), Low pass filter orde dua butterworth, jaringan umpan balik, dan kompensator dapat dilihat dari Gambar 5.

$\mathrm{V}_{\mathrm{F}}$ dibandingkan dengan sinyal audio, dan sinyal kesalahan yang dihasilkan E (t) adalah ditentukan oleh kompensator PI. Terminal input positif komparator terhubung ke E(t) yang merupakan output dari kompensator PI, dan terminal input negatif dari komparator terhubung ke $\mathrm{V}_{\text {TRIANGLE }}$ yang berasal dari generator gelombang segitiga. Sinyal kesalahan $E$ (t) dibandingkan dengan $V_{\text {TRIANGLE }}$ untuk menghasilkan switching control gelombang. Gelombang switching mendorong Penguat daya output. Sebuah low pass filter digunakan untuk menghilangkan sinyal frekuensi tinggi dan mengembalikan sinyal audio asli. 


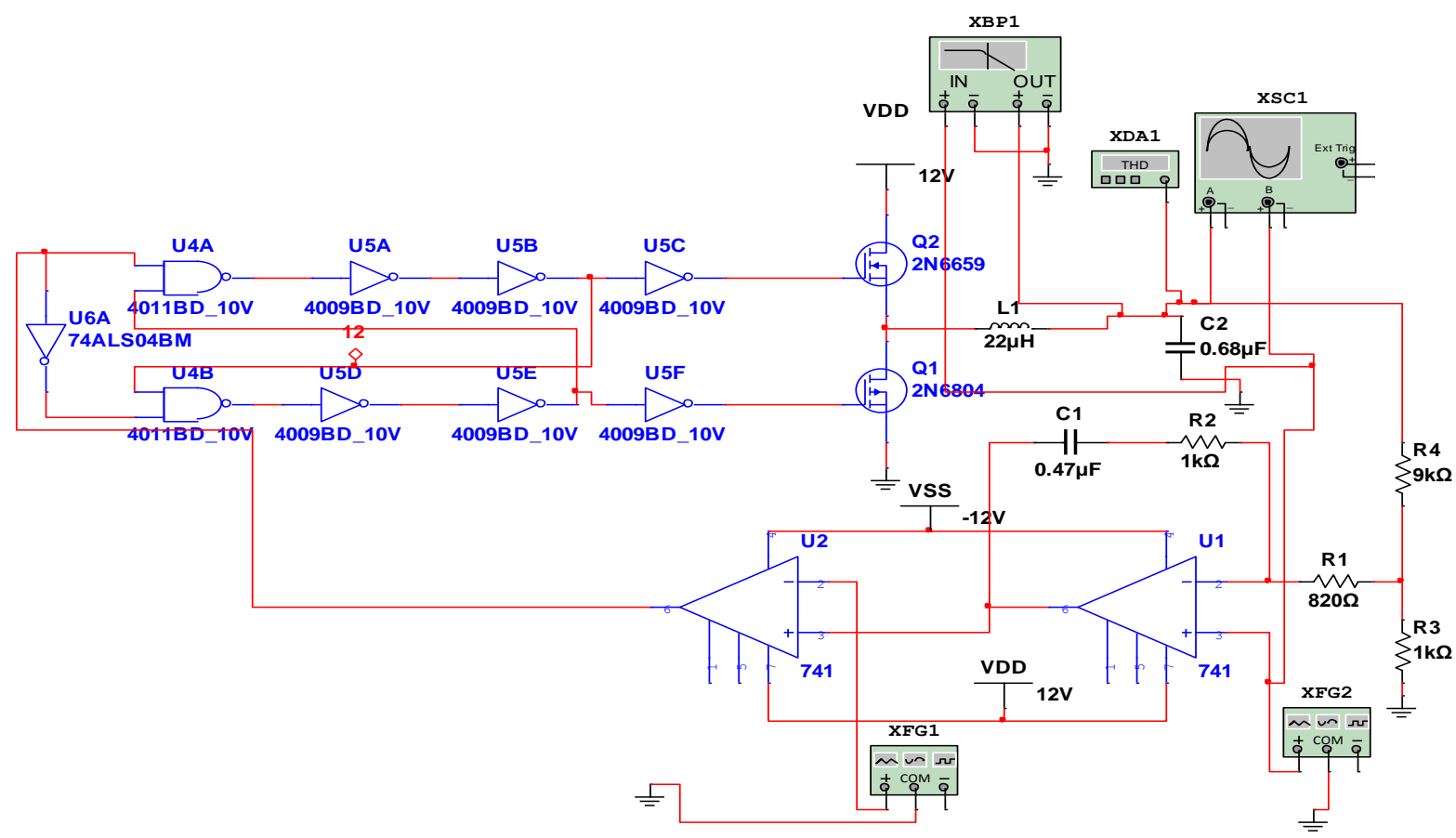

Gambar 7 Schematic Penguat Audio Kelas D Tanpa Beban

Kompensator PI digunakan untuk meningkatkan gain loop frekuensi rendah dan mempunyai redaman yang lebih baik terhadap gangguan frekuensi rendah. Rangkaian umpan balik resistor adalah pembagi tegangan yang terdiri dari resistor presisi. Model Matlab Simulink V17 ditunjukkan pada Gambar 6 dan Rangkaian schematic menggunakan Software Multisim V14.0 ditunjukkan oleh Gambar 7.

Fungsi alih Kompensator PI yang akan dioptimasi menggunakan metode MQPSO dapat ditulis pada Persamaan (5).

$$
G_{C}(S)=\frac{s C_{2} R_{2}+1}{s C_{2} R_{1}}
$$

Nilai $\mathrm{C}_{2}, \quad \mathrm{R}_{2}$ dan $\mathrm{R}_{1}$ akan diberikan range nilai menggunakan Software Matlab untuk mencari nilai terbaik dengan optimasi MQPSO. Nilai terbaik tersebut akan dimasukkan kembali ke Blok Simulink untuk mengetahui perbandingan THD sebelum dioptimasi menggunakan nilai awal dan sesudah dioptimasi. Range nilai awal yang akan diberikan pada persamaan (2-5) sebagai percobaan secara trial dan error sebagai berikut:

$$
\begin{array}{ll}
\mathrm{C}_{2} & : 0.1 \mu \mathrm{F}-0.47 \mu \mathrm{F} \\
\mathrm{R}_{2} & : 82 \Omega-1 \mathrm{~K} \Omega \\
\mathrm{R} 1 & : 50 \Omega-1 \mathrm{~K} \Omega
\end{array}
$$

Fungsi alih low pass filter orde 2 butterworth dapat ditulis pada Persamaan (6).

$$
H_{L R C}(S)=\left(\frac{1}{L C} / S^{2}+\frac{1}{R C} S+\frac{1}{L C}\right)
$$

dengan rincian sebagai berikut :

$$
\begin{array}{ll}
\mathrm{L} & : 22 \mu \mathrm{H} \\
\mathrm{C} & : 0.68 \mu \mathrm{F} \\
\mathrm{R} & : 8 \Omega
\end{array}
$$

Nilai pada persamaan fungsi alih ini akan dimasukkan pada blok LPF Simulink.

\section{F. Proses Optimasi}

Algoritma MQPSO merupakan algoritma optimasi yang akan digunakan pada penelitian ini. Parameter Kompensator Proportional-Integral (PI) yang dioptimasi adalah nilai C2, R2 dan R1 pada blok fungsi alih Kompensator menggunakan Metode MQPSO. Proses optimasi MQPSO yang ditunjukan diagram alir pada Gambar 8,

\section{PSEUDO CODE MOPSO}

\section{Begin:}

Default random (Step (1) and Step (2))

\section{STEP (1) $\longrightarrow$
PARAMETER SETTING.}

Max iterations, Swarm_size.

$\operatorname{For}(\mathbf{i}, \mathbf{j})=1$ to Swarm_size, Component $\boldsymbol{C} \boldsymbol{2}_{(i, j)}, \boldsymbol{R} \boldsymbol{1}_{(i, j)}, \boldsymbol{R} \boldsymbol{2}_{(i, j)}$ using random distribute with minimum and maximum range. With output is matrix [1 Swarm_size] each component $\boldsymbol{C} 2, \boldsymbol{R} \mathbf{1}, \boldsymbol{R} 2(\boldsymbol{R} 2>\boldsymbol{R} \mathbf{1})$.

End

Component [C2 R2 R1] in one matrix table.

\section{STEP (2) \\ INITIALIZATION SWARM \\ POSITION.}

Swarm Parameter.

For $(\mathbf{i}, \mathbf{j})=1$ to Swarm_size,

Swarm_position $\boldsymbol{C} \mathbf{2}_{(i, j)}, \boldsymbol{R} \mathbf{1}_{(i, j)}, \boldsymbol{R} \mathbf{2}_{(i, j)}$ using random distribute with minimum and maximum range.

With output is matrix [1 Swarm_size] each Swarm_position $\boldsymbol{C 2}, \boldsymbol{R} \mathbf{1}, \boldsymbol{R} 2$.

\section{End}

Swarm [C2 R2 R1] in one matrix table.

Best Local position = Swarm.

Calculate Fitness using Ackley's Function with Best Local position.

Find the Local Best using Minimum the Best Fitness. 


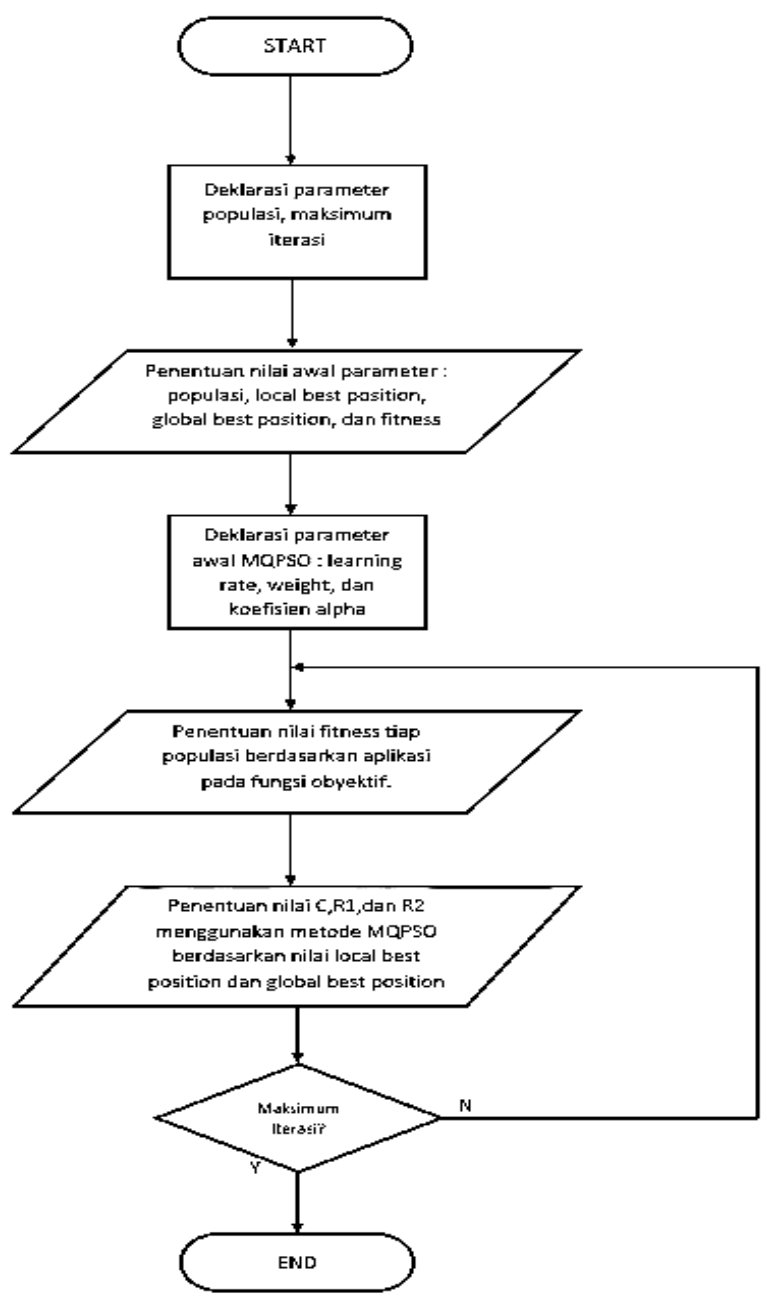

Gambar 8. Flow Chart Optimasi Metode MQPSO

$\underline{\operatorname{STEP}(3)}$

MQPSO.

Initialize QPSO parameters.

Iteration: 1

While iteration < Max iteration and Max Value,

Do

Calculate Alpha, Mean best, Fitness Global Using Ackley's Function.

Error Value, Global Best by Minimum Fitness and Error Value.

Iteration: +1

End

STEP (4)

STORE THE RESULT. Best.

Get Best Component by indexing the minimum Global

Simulating to Plant, using Best Component and get THD and $\boldsymbol{E R R O R}$.

Plotting All Result.

If THD (j) > THD (i) in simulation,

Then Increase Max Iteration until Fitness

Convergence.

End

\section{HASIL DAN PEMBAHASAN}

Pengujian sistem Penguat audio kelas D ini dilakukan pada 2 tahapan, yaitu meliputi pengukuran THD menggunakan Simulink dan Pengukuran waktu Kestabilan Rangkaian penguat menggunakan Software Multisim. Perangkat keras (Hardware) yang digunakan adalah Laptop dengan spesifikasi Processor Intel Core i5-4310U Gen4, DDR3 12GB \& SSD 120GB. Sedangkan perangkat lunak (Software) yang digunakan adalah Microsoft Windows 10, Multisim V14 dan Matlab V17.

A. Pengujian Sistem Penguat Audio Kelas D loop tertutup dengan Kompensator PI (tanpa optimasi) dan menggunakan optimasi dengan Software Multisim V14.0

Pada pengujian ini, Range nilai awal yang akan diberikan sebagai percobaan secara trial dan error sebagai berikut :

$\mathrm{C}_{2} \quad: 0.1 \mu \mathrm{F}-0.47 \mu \mathrm{F}$

$\mathrm{R}_{2}: 82 \Omega-1 \mathrm{~K} \Omega$

$\mathrm{R} 1: 50 \Omega-1 \mathrm{~K} \Omega$

Nilai komponen C2, R2 dan R1 (tanpa optimasi) yang digunakan pada kompensator sebagai berikut :

End 


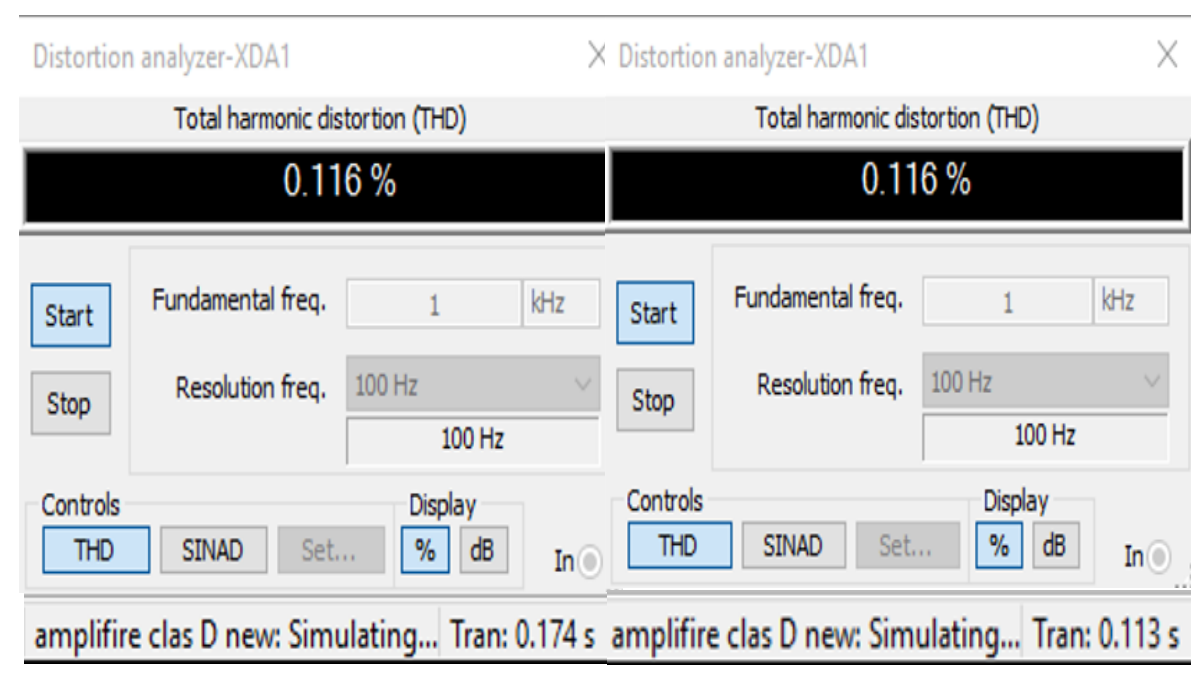

Gambar 9. Perbandingan THD terhadap waktu (Tanpa Optimasi dan Optimasi MQPSO)

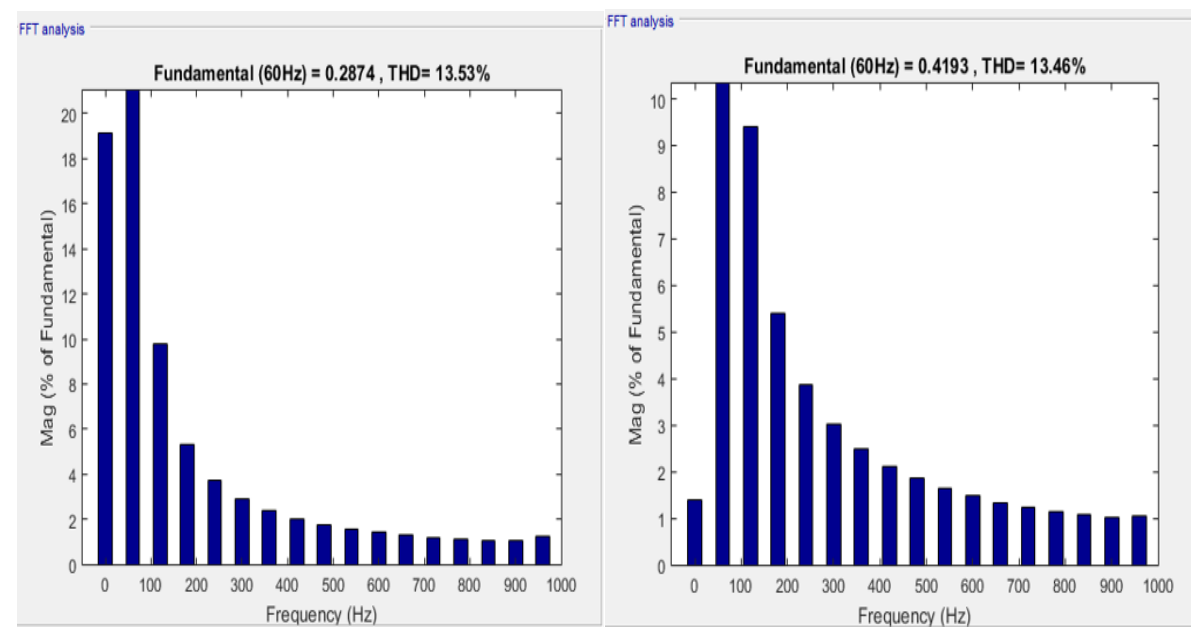

Gambar 10. Analisis THD menggunakan FFT Tool

$\mathrm{C}_{2}: 0.47 \mu \mathrm{F}$

$\mathrm{R}_{2}: 1 \mathrm{~K} \Omega$

$\mathrm{R} 1 \quad: 820 \Omega$

Nilai komponen C2, R2 dan R1 (optimasi MQPSO) yang digunakan pada kompensator sebagai berikut :

$\mathrm{C}_{2}: 0.3325 \mu \mathrm{F} \approx 0.33 \mu \mathrm{F}$

$\mathrm{R}_{2}: 897 \Omega \approx 900 \Omega$

$\mathrm{R} 1 \quad: 989 \Omega \approx 1000 \Omega$

Hasil simulasi THD ditampilkan menggunakan Distortion Analyzer - XDA1 dan pencapaian waktu THD terbaik ditampilkan pewaktu Multisim dilihatkan pada Gambar 9.

B. Pengujian Sistem Penguat Audio Kelas D loop tertutup dengan Kompensator PI (tanpa optimasi) dan menggunakan optimasi dengan Matlab Simulink V17

Pada pengujian ini, digunakan blok Simulink untuk mencari THD dengan memberikan nilai komponen C2, R2, dan R1sebelum dioptimasi dan sesudah dioptimasi ke persamaan fungsi alih kompensator PI.

Sinyal audio input $: 1 \mathrm{KHz}$ (Range $20 \mathrm{~Hz}-20 \mathrm{KHz}$ )

Sinyal segitiga $: 25 \mathrm{KHz}$

Gain feedback $\quad: 0.1$

Gain PWM $\quad: 1 / 0.000002$

Gain Driver $\quad: 4$
Parameter Low Pass Filter butterworth orde-2

$$
\begin{array}{ll}
\mathrm{L} & : 22 \mu \mathrm{H} \\
\mathrm{R} & : 8 \Omega \\
\mathrm{C} & : 0.68 \mu \mathrm{F}
\end{array}
$$

Analisis THD pada frekwensi $60-1000 \mathrm{~Hz}$ digunakan Fast Fourier Transform (FFT) tool pada Simulink ditunjukkan pada Gambar 10, dihasilkan nilai THD $13.53 \%$ sebelum dioptimasi dan $13.46 \%$ setelah dioptimasi.

\section{Analisis Hasil Pengujian}

Pada Gambar 9 Distortion Analyzer - XDA1 menampilkan nilai THD terbaik sebelum dioptimasi sebesar $0.116 \%$ dengan waktu kestabilan 0.174 s sedangkan setelah dioptimasi sebesar $0.116 \%$ dengan waktu kestabilan $0.113 \mathrm{~s}$. Hasil tersebut menunjukkan waktu yang dibutuhkan untuk mencapai kestabilan sistem lebih cepat setelah dioptimasi menggunakan MQPSO. Selisih waktu sebesar 0.063s.

Pada Gambar 10 menggunakan analisis FFT tool Simulink Matlab V17 didapatkan hasil nilai THD sebelum dioptimasi sebesar $13.53 \%$ dan nilai THD menggunakan optimasi MQPSO sebesar $13.46 \%$. Selisih nilai THD setelah dan sebelum optimasi sebesar $0.07 \%$.

\section{KESIMPULAN DAN SARAN}


Penelitian ini dilakukan untuk mendapatkan THD yang lebih baik dan waktu kestabilan yang lebih cepat pada sebuah Sistem Penguat audio kelas D dengan mengoptimasi parameter Kompensator PI menggunakan Metode Modified Quantum behaved Particle Swarm Optimization (MQPSO). Hasilnya menunjukkan bahwa dengan tambahan metode MQPSO untuk mengoptimasi parameter kompensator PI yang terdiri dari C2, R2, dan R1 dengan pengujian Software Multisim V14.0 dan Simulink Matlab V17 didapatkan selisih waktu sebesar $0.063 \mathrm{~s}$ untuk mencapai kestabilan dan selisih THD optimal sebesar $0.07 \%$. Sehingga penggunaan metode MQPSO ini terbukti dapat membantu dalam hal optimasi sistem penguat audio kelas D.

Pengembangan selanjutnya pada penelitian ini dapat dilakukan dengan membangun sebuah simulasi sistem penguat audio kelas D yang ideal dilihat dari nilai THD yang minimum, efisiensi di atas $90 \%$ dan waktu kestabilan yang lebih cepat (mendekati real time). Metode optimasi lain seperti Cuckoo Search Algorithm (CSA), Firefly Algorithm (FA), dan lainnya yang terbaru bisa digunakan untuk mengoptimalkan sistem.

\section{DAFTAR PUSTAKA}

[1] Y.-S. Hwang, J.-H. Shen, J.-J. Chen, dan M.-R. Fan, “A THD-reduction high-efficiency audio amplifier using inverter-based OTAs with filter-output feedback," Microelectron. J., vol. 45, no. 1, hlm. 102-109, Jan 2014, doi: 10.1016/j.mejo.2013.10.007.

[2] Y.-S. Hwang, J.-H. Shen, J.-J. Chen, dan M.-R. Fan, “A THD-reduction high-efficiency audio amplifier using inverter-based OTAs with filter-output feedback," Microelectron. J., vol. 45, no. 1, hlm. 102-109, Jan 2014, doi: 10.1016/j.mejo.2013.10.007.

[3] M. Kinyua, R. Wang, dan E. Soenen, "Integrated 105 dB SNR, 0.0031\% THD+N Class-D Audio Amplifier With Global Feedback and Digital Control in $55 \mathrm{~nm}$ CMOS," IEEE J. Solid-State Circuits, vol. 50, no. 8, hlm. 1764-1771, Agu 2015, doi: 10.1109/JSSC.2015.2420314.

[4] Wenfeng Yu, W. Shu, dan J. S. Chang, "A low THD analog Class D Amplifier based on self-oscillating modulation with complete feedback network," dalam 2009 IEEE International Symposium on Circuits and Systems, 2009, hlm. 2729-2732, doi: 10.1109/ISCAS.2009.5118366.

[5] T. F. S. Jr dan E. M. Kim, Fundamentals of Electronics: Book 2: Amplifiers: Analysis and Design. Morgan \& Claypool Publishers, 2015.

[6] J. S. Chang, Bah Hwee Gwee, Yong Seng Lon, dan Meng Tong Tan, "A novel low-power low-voltage Class D amplifier with feedback for improving THD, power efficiency and gain linearity," dalam ISCAS 2001. The 2001 IEEE International Symposium on Circuits and Systems (Cat. No.01CH37196), 2001, vol. 1, hlm. 635-638 vol. 1, doi: 10.1109/ISCAS.2001.921936.

[7] C. K. Lam, M. T. Tan, S. M. Cox, dan K. S. Yeo, "Class-D Amplifier Power Stage With PWM Feedback Loop," IEEE Trans. Power Electron., vol. 28, no. 8, hlm. 3870-3881, Agu 2013, doi: 10.1109/TPEL.2012.2230027.

[8] S. H. M. Amin dan A. Adriansyah, "Particle Swarm Fuzzy Controller for Behavior-based Mobile Robot," dalam 2006 9th International Conference on Control, Automation, Robotics and Vision, Singapore, 2006, hlm. 1-6, doi: 10.1109/ICARCV.2006.345293.

[9] I. Fadloullah, A. Mechaqrane, dan A. Ahaitouf, "Butterworth Low Pass filter design using evolutionary algorithm," dalam 2017 International Conference on Wireless Technologies, Embedded and Intelligent Systems (WITS), 2017, hlm. 1-6, doi: 10.1109/WITS.2017.7934661.

[10] O. U. Rehman, S. Yang, S. Khan, dan S. U. Rehman, "A Quantum Particle Swarm Optimizer With Enhanced Strategy for Global Optimization of Electromagnetic Devices," IEEE Trans. Magn., vol. 55, no. 8, hlm. 1-4, Agu 2019, doi: 10.1109/TMAG.2019.2913021.

[11] D. Self, Audio Power Amplifier Design. Routledge, 2013.

[12] R. G. Gupta, Audio and Video Systems: Principles, Maintenance and Troubleshooting. Tata McGraw-Hill Education, 1995.

[13] M. T. Tan, J. S. Chang, Z. H. Cheng, dan Y. C. Tong, "Analysis and two proposed design methodologies for optimizing power efficiency of a class D amplifier output stage," dalam ISCAS '98. Proceedings of the 1998 IEEE International Symposium on Circuits and Systems (Cat. No.98CH36187), 1998, vol. 1, hlm. 281284 vol.1, doi: 10.1109/ISCAS.1998.704416.

[14] E. Gaalaas, "Class D Audio Amplifiers: What, Why, and How," hlm. 7, 2006.

[15] J. S. Chang, Meng-Tong Tan, Zhihong Cheng, dan YitChow Tong, "Analysis and design of power efficient class D amplifier output stages," IEEE Trans. Circuits Syst. Fundam. Theory Appl., vol. 47, no. 6, hlm. 897902, Jun 2000, doi: 10.1109/81.852942.

[16] J. Honda dan J. Adams, "Application Note AN-1071," Int. Rectifier, 2005.

[17] P. Charles L., R. D. Harbor, dan R. J. WIDODO, Sistem Kontrol:Dasar-dasar (Feedback Control Systems 3e), vol. 2. Jakarta: Prenhallindo, 1997.

[18] Zuhal, Dasar tehnik Tenaga Listrik dan Elektronika Daya, Cet. 1. Jakarta: Gramedia, 1995. 
